\title{
A Proposed Supplemental Teaching Model For Enhancing Students' Understanding Of Sarbanes Oxley
}

James Specht, Concordia, College, USA

Albert Kagan, Arizona State University, USA

Scott D. Maanum, Deloitte \& Touche, USA

\begin{abstract}
The Sarbanes Oxley Act of 2002 brought about major changes in how accounting firms conduct audits of publicly traded companies. Corporate officials have additional responsibilities in the areas of internal controls and financial reports. In addition there is a new organization responsible for established auditing standards for publicly traded companies, the Public Company Accounting Oversight Board. Accordingly, there are new requirements and responsibilities for auditors of publicly traded companies. In effect, the emergence of separate auditing standards for publicly traded companies and for companies that are not publicly traded is creating two distinct fields of auditing. These changes require a different approach to teaching auditing to accounting students. This article proposes one approach to teaching these significant changes for entry level auditors.
\end{abstract}

Keywords: Auditing, Sarbanes-Oxley, Curriculum Design, Compliance

\section{A Proposed Supplemental Teaching Model For Enhancing Students' Understanding Of Sarbanes Oxley}

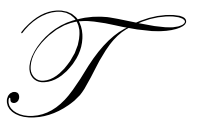

he Sarbanes-Oxley Act of 2002 (Public Company Accounting Reform and Investor Protection Act of 2002) was enacted on July 30, 2002 in response to numerous corporate irregularities that were heightened by lack of sufficient accounting oversight (Perino, 2002, Langevoort, 2006, Coates, 2007). Major firms that were involved in questionable accounting practices were Enron, Tyco International, HealthSouth, Peregrine Systems and WorldCom. Financial mismanagement pertaining to these firms cost investors billions of dollars in equity (and real value). This erosion of investor equity occurred when stock prices dropped substantially as a result of public disclosure of the financial mismanagement. Public confidence in the nation's securities markets was seriously shaken and eventually fostered major governmental intervention. This legislation has been labeled "the most far-reaching reforms of American business practices since the time of the second Roosevelt Administration".

In essence the lack of audit compliance within the structure of corporate governance led to audit failure that was at the center of the reform process. This set of audit and independence irregularities was a contributing factor to the enactment of the Sarbanes-Oxley legislation (Chaney and Philipich, 2002; Frankel, Johnson and Nelson, 2002). Sarbanes-Oxley (SOX) establishes a set of enhanced standards for all U.S. publicly traded firms, boards of directors, corporate financial management operations, and public accounting firms (Romero and Berenson, 2002, Jain and Rezaee, 2006). This legislation does not apply to privately held firms. The Act itself contains 11 sections, ranging from detailed Corporate Board responsibilities and practices to specific criminal penalties for infractions (Public Law 107-204). The Securities and Exchange Commission (SEC) is also required to implement necessary rulings on legislative requirements to comply with this law.

As part of the SOX Act, a new quasi-public agency, the Public Company Accounting Oversight Board (PCAOB) was established. PCAOB is responsible for the overseeing, regulating, inspecting, and disciplining as 
appropriate public accounting firms that fail in their role as auditors of public companies. SOX also address the issue of auditor independence, corporate governance accountability, internal control assessment, and enhanced financial disclosure practices (Public Oversight Board. 2002; Public Company Accounting Oversight Board, 2004, Annual Report).

Debate continues over the perceived benefits and costs of SOX implementation and effectiveness. Supporters argue that the legislation was necessary and has played a useful role in restoring public confidence in US capital markets by strengthening internal accounting controls and defining the rules of engagement of corporate boards of directors. Detractors of SOX cite the cost increases due to compliance, lack of evidence of intended benefits, and the additional scrutiny placed upon pubic firms and the accounting profession (Coates, 2007).

This paper provides a framework for integrating the issues and concepts of Sarbanes-Oxley into the auditing course of the accounting curriculum. The current auditing course typically covers SOX related topics in one chapter on regulation and one chapter on internal controls. The change in the relationship of the auditor and the client, the affect on audit fees, the reduction of business risk, and the enhanced effectiveness of the audit are not discussed. Expanded use of the client's internal audit function, reduction in audit risk, and improved internal controls are not discussed in depth in current auditing textbooks.

As the accounting profession changes to adhere to the regulatory requirements of SOX and the oversight influences of PCAOB, the auditing class must be adaptive to the inclusion of SOX as a set of discussion topics that affects all aspects of the audit. Sections 302 and 404 should be understood within the context of auditor independence, internal control mandates, internal control assessments, information technology relationships, implications for smaller sized public firms and the effectiveness of the legislation relative to the Congressional intent.

In designing a set of modules within the auditing class that addresses the Sarbanes-Oxley Act, the direction and focus must be on the Act's impact upon the accounting firm, the client, and the role of the auditor as an independent agent within the corporate governance structure. The module approach will allow students to understand the legislative intent, the role of the agent/principal in the audit process, internal control design and assessment within the SOX structure, PCAOB's role in improving the audit function, and how to assess the effectiveness of SOX.

A matrix of major topics is presented below. This supplemental material is designed to integrate several student research experiences within the context of SOX. Student research applications will be focused upon the broad headings of SOX effectiveness, small firm implications of SOX, cost-benefit assessment of the SOX process, corporate governance and SOX, international firm's interaction with SOX and the role of the auditor in the governance design paradigm.

As accounting students become familiar with the components of the Sarbanes-Oxley Act, a set of classroom discussions will progress. These applications will bring the SOX view into the framework of corporate responsibility, governance, agent-principal conveyance, and fraud mitigation practices. This phase of the course will entail a student driven research project on a specific topic within the general framework of the SOX mandate.

One research topic would include having students contrast how audits would differ for a publicly traded company and for a nonpublic company. Students would gain an appreciation of how a two tier regulatory system is developing and how audit practices would differ.

A second research topic would be for students to assess internal control structures for both a SEC client and a small privately held company. Audit students would be required to assess audit risk, internal control risk, and a specific client's susceptibility to financial improprieties. Students would gain an appreciation of how SOX's actually benefits the investor, the client, and the auditor. 
Table 1: Topics contained in SOX Discussion Framework

\begin{tabular}{|c|c|c|c|}
\hline Module & Concepts & Process & Outcome \\
\hline $\begin{array}{l}\text { Cost Benefit of } \\
\text { SOX }\end{array}$ & $\begin{array}{l}\text { Measure Effectiveness vs. } \\
\text { Intent }\end{array}$ & Evaluate existing literature and readings & $\begin{array}{l}\text { Report/Presentation } \\
\text { Model (if needed) }\end{array}$ \\
\hline Section 302 & $\begin{array}{l}\text { Internal Control } \\
\text { Certifications }\end{array}$ & $\begin{array}{l}\text { Self report material weaknesses in internal } \\
\text { controls---Discuss this approach-SWOT } \\
\text { analysis }\end{array}$ & $\begin{array}{l}\text { Process control } \\
\text { recommendations }\end{array}$ \\
\hline Section 404 & $\begin{array}{l}\text { Assessment of Internal } \\
\text { Controls }\end{array}$ & $\begin{array}{l}\text { Internal control report, affirmation of } \\
\text { management responsibility }\end{array}$ & $\begin{array}{l}\text { Design an internal } \\
\text { control framework }\end{array}$ \\
\hline Section 404 & Smaller Public Firms & $\begin{array}{l}\text { SEC assessment of implementation based on } \\
\text { firm size }\end{array}$ & $\begin{array}{l}\text { Cost/benefit analysis of } \\
\text { firm size structure }\end{array}$ \\
\hline Section 404 & $\begin{array}{l}\text { Information Technology } \\
\text { Interaction }\end{array}$ & $\begin{array}{l}\text { Information technology controls that address } \\
\text { financial risk }\end{array}$ & $\begin{array}{l}\text { IT control } \\
\text { recommendations }\end{array}$ \\
\hline $\begin{array}{l}\text { SOX and Non- } \\
\text { US Companies }\end{array}$ & $\begin{array}{l}\text { International Aspects of this } \\
\text { Act }\end{array}$ & $\begin{array}{l}\text { Bill 198 -, Canada, version of Sarbanes-Oxley } \\
\text { Act, J-SOX - Japanese version of Sarbanes- } \\
\text { Oxley Act, CLERP9 - Australian Corporate } \\
\text { reporting and disclosure law, LSF - French } \\
\text { version of Sarbanes-Oxley Act, L262/2005 - } \\
\text { Italian version of Sarbanes-Oxley Act for } \\
\text { financial services institutions, King Report - } \\
\text { South African version on Corporate } \\
\text { Governance }\end{array}$ & $\begin{array}{l}\text { Comparative analysis of } \\
\text { international } \\
\text { implications }\end{array}$ \\
\hline
\end{tabular}

This type of approach to more directly address the Sarbanes-Oxley Act will enhance the overall content of the audit course with respect to compliance and strengthen the understanding of the auditor's role in corporate governance. It also will improve students understanding of the two tier approach to auditing. The modules suggested in this paper can be further customized for instructor needs and pedagogical design.

\section{AUTHOR INFORMATION}

James Specht is an Associate Professor of Accounting and Certified Public Accountant. He teaches at the Concordia College, School of Business; Moorhead, Minnesota. He has taught the auditing course for over ten years and is a practicing accountant. His research interest are audit risk and fraud detection. He has refereed proceedings and publications in The International Applied Business Research Conference and in The Journal of Applied Business Research.

Albert Kagan is a Professor of Management at Arizona State University. His research activities are in the area of entrepreneurial design applications, strategic management, and electronic commerce. Dr. Kagan's research has resulted in over 130 refereed scholarly and professional publications in journals and conference proceedings. Representative publications have appeared in the in the following: Journal of Management Information Systems, Journal of Marketing Research, Omega, Journal of Economics and Business, Journal of Business Logistics and Entrepreneurship: Theory and Practice among others. Professor Kagan's funded research projects have totaled over $\$ 11.0$ million. He is the editor of a book on E-Commerce applications and serves on the editorial board for an innovation journal.

Scott D. Maanum graduated from Concordia College with a degree in accounting in May 2008. He is currently employed as a staff accountant with Deloitte \& Touche in Minneapolis, Minnesota.

\section{REFERENCES}

1. Chaney, P.K.and R. L. Philipich, 2002. "Shredded Reputation: The Cost of Audit Failure." Journal of Accounting Research, Vol. 40( ) pp.1221-1245.

2. Coates, J. C., IV, 2007. "The Goals and Promise of the Sarbanes-Oxley Ac." Journal of Economic Perspectives, Vol. 21 (1) pp. 91-116. 
3. Frankel, R.M., M. F. Johnson K. K. Nelson, 2002. "The Relation Between Auditors' Fees for Nonaudit Services and Earnings Management." The Accounting Review, Vol. 77 (Supp) pp. 71-105.

4. Jain, P.K. and Z. Rezaee, 2006.“The Sarbanes-Oxley of 2002 and Security Market Behavior: Early Evidence." Contemporary Accounting Research, Vol. 23(3) pp 629-654.

5. Langevoort, D.C., 2006.“Internal Controls after Sarbanes-Oxley: Revisiting Corporate Law's Duty of Care as Responsibility for Systems." Journal of Corporation Law, Vol.31(3)pp 949-973.

6. $\quad$ Perino, M.A., 2002."Enron's Legislative Aftermath: Some Reflections on the Deterrence Aspects of the Sarbanes-Oxley Act of 2002.” St.John's Law Review, Vol.76 (Fall)pp 671.

7. Public Company Accounting Oversight Board, 2004 Annual Report.

8. Public. Law (Sarbanes-Oxley Act) No. 107-204 116 Stat. 145 (2002).

9. Public Oversight Board. 2002. "The Road To Reform: A White Paper From The Public Oversight Board On Legislation To Create A New Private Sector Regulatory Structure For The Accounting Profession.

10. Romero, S., and A. Berenson, 2002. "WorldCom Says It Hid Expenses, Inflating Cash Flow \$3.8 Billion." The New York Times, June 26, 2002, pp. A1-C2. 